\title{
Franz Brentano's Influence on Ukrainian Philosophy: A Methodological Introduction to Research 1
}

\author{
Stepan Ivanyk \\ Kazimierz Twardowski Philosophical Society of Lviv
}

\begin{abstract}
This article ponders, for the first time, the question of whether Austrian philosopher Franz Brentano (1838-1917) influenced the development of the school of Ukrainian philosophy. It employs Anna Brożek's methodology to identify philosophers' influence on one another (distinctions between direct and indirect influence, active and passive contact, etc.); concepts of institutional and ideological conditions of this influence are also considered. The article establishes, first, that many Ukrainian academics had institutional bonds with Brentano's students, especially Kazimierz Twardowski at the University of Lviv. Second, it identifies an ideological bond between Brentano and his hypothetical Ukrainian "academic grandsons." Particularly, a comparative analysis of works on the history of philosophy of Brentano and the Ukrainian Ilarion Svientsits'kyi (1876-1956) reveals that the latter took over Brentano's a posteriori constructive method. These results allow to draw a conclusion about the existence of Ukrainian Brentanism, that not only brings new arguments into the discussion about the tradition of and prospects for the development of analytic (scientific) philosophy on Ukrainian ground, but also opens new aspects of the modernization of Ukrainian society in general (from the end of the nineteenth century to the present day).
\end{abstract}

Keywords: Franz Brentano, Brentanism, Austrian philosophy, Ukrainian philosophy, the Lviv School of Philosophy.

\section{INTRODUCTION}

$\mathrm{F}$ ranz Brentano ${ }^{2}$ is considered to be the founder of the Austrian philosophical tradition that emerged and developed to a large extent in

\footnotetext{
1 This paper is a part of the project number 2015/18/E/HS1/00478, financed by the National Science Centre in Cracow, Poland.

2 Basic biographical facts: Brentano was born in Marienberg am Rhein in 1838. He studied philosophy at the universities of Munich, Würzburg, Berlin, and Münster. In 1862 he defended his dissertation under the title On the Several Senses of Being in Aristotle and in 1866 he defended his habilitation thesis The Psychology of Aristotle: In Particular His Doctrine of the Active Intellect. From 1866 to 1873 he lectured at the University of Würzburg and from 1874 to 1895 he lectured at the University of
} 
opposition to the ideas and style of German transcendental and critical philosophy, and especially the philosophy derived from the Kantian tradition. At the same time, Brentano's significance went beyond Austrian philosophy; his influence on the development of all nineteenth century European philosophy is believed to be enormous, particularly regarding trends such as analytical philosophy and phenomenology. This might seem strange considering that Brentano published very little during his lifetime and his name is not usually mentioned among the most important philosophers of that century. The main reason for that "invisibility" lies in his unique approach to philosophy: like Socrates, he spread his ideas mostly through his lectures at the University of Vienna and through private conversations with his followers (Albertazzi et al. 3). It could be said that he was a typical "speaking" rather than "writing" philosopher.

The key to understanding the Brentano phenomenon lies with his followers who, while treating their teacher's concepts as a starting point, created their own schools and philosophical trends through a critical elaboration or negation of those concepts. Barry Smith, a scholar who studies the academic legacy of Brentano and his school, writes: "A table of Brentano's students and of his students' students would thus come close to embracing all of the most important philosophical movements of the twentieth century on the continent of Europe" (Austrian Philosophy 19).

It is enough to mention such famous followers and establishers of new trends as Edmund Husserl (phenomenology), Alexius Meinong ("theory of objects"), Sigmund Freud (psychoanalysis), and Christian von Ehrenfels (Gestalt psychology). Many of Brentano's followers contributed to the spread of Brentano's influence outside Vienna by establishing their own schools in other large cultural centres of the Austrian-Hungarian Empire and Germany: Alexius Meinong (in Graz), Franz Hillebrand (in Innsbruck), Kazimierz Twardowski (in Lviv), Anton Marty (in Chernivtsi and Prague), Christian von Ehrenfels (in Prague), Tomáš Masaryk (in Prague), Carl Stumpf (in Berlin) (Surman 354-57). Other philosophers, such as Alois Höfler, continued Brentano's tradition at the University of Vienna after his departure.

There is one more dimension of the significance of Brentano for the development of modern philosophy. The point is that according to the established tradition, all modern Western philosophy can be divided into two competing camps: analytic and non-analytic (or continental) philosophy. What is the fundamental difference between analytic and nonanalytic philosophy, and why is this difference so important? Smith answers the question as follows:

Vienna. Brentano died in Zürich in 1917. His major work, Psychology from an Empirical Standpoint, was published in 1874. 
What, then, is the moment of unity of this "Continental Philosophy"? What is it that Heidegger and Derrida and Luce Irigaray have in common, which distinguishes them from phenomenologists such as Reinach or Scheler or the famous Daubert? The answer, it seems, is: antipathy to science, or more generally, antipathy to learning and to scholarly activity, to all the normal bourgeois purposes of the Western University (and we note in passing that, as far as phenomenology is concerned, it was Heidegger who was responsible for terminating that previously healthy scientific line which had brought forth such masterpieces as Brentano's Psychology from an Empirical Standpoint and Husserl's Logical Investigations). This rejection of the values associated with normal scholarly activity is combined, further, at least in the case of those French thinkers accredited as "Continental Philosophers" - with a substitution of politics for science (where politics, too, is to be understood in a broad sense-a sense broad enough to include also the adolescent fringe). Philosophy thereby becomes transformed into a strange type of ideologically motivated social criticism. ("Why Polish Philosophy" 19-20)

Thus, according to Smith, the finer distinction between analytic and non-analytic philosophy is that the first is more closely connected with science (it is science for science), and the second is more closely connected to politics (it is motivated by ideological circumstances). To paraphrase Smith, one could say that analytic philosophy is scientific, and that nonanalytic philosophy-unscientific. It is believed that nowadays the centres of analytical philosophy are Great Britain, the USA, and the countries of Australasia and Scandinavia, while continental Europe (represented primarily by France and Germany) is the main source of non-analytic philosophy. It is in this context that Brentano's importance is clarified, as he was one of the precursors, so to speak, of the emergence of analytic philosophy in continental Europe. He was convinced that philosophy, as the "queen of sciences," should fulfill the conditions of scientificity itself-that is, that philosophy should use a strict scientific method. He saw conceptual analysis to be the proper method of philosophical cognition, as conceptual analysis not only explains and specifies the knowledge already possessed, but also expands the existing knowledge and acquires new knowledge. He perceived the primary roles of this analytic method to be to protect philosophy from sterile speculation and to give the problems under consideration unequivocal sense and precision. He understood philosophy as a metascience, providing tools for the analysis of specific empirical problems, rather than as a synthetic worldview (which non-analytic philosophy tends to create).

When we discuss Brentano's influence on European philosophy, we mean not only western European philosophy, but also eastern European philosophy. Polish and Czech sections of "Brentanism" (Dąmbska; Novák) emerged thanks to the academic and pedagogic activities of Twardowski 
and Masaryk. Great Russian philosophers such as Nikolay Lossky, Semyon Frank, and Gustav Shpet admitted that their works on philosophy were influenced by the ideas of Brentano (Abushenko 94-98). Another Russian philosopher, George Katkov, at one time was even a manager of Brentano's archive in Prague. Therefore, the complete lack of research on Brentano's influence on Ukrainian philosophy seems odd. I believe there are two reasons for this lack of interest. First, the works of Ukrainian philosophers written in Ukrainian at the end of the nineteenth century and the first decades of twentieth century are usually unavailable to Western researchers of Brentanism (because of the language barrier, for instance). Second, the lack of research in Ukraine is due to the fact that the history of Ukrainian philosophy as a separate academic branch is to a large extent still in its "infancy," as it started to develop freely only after 1991.

Thus, in the following article, I ask for the very first time: did Brentano influence Ukrainian philosophy? The answer to this question is not only of historical significance. To account for the development of analytic (scientific) philosophy in some countries, and its absence in others, Smith cites the directly proportional relation of this philosophy to the level of modernization of the society in which it develops:

Why did scientific philosophy not take root in, say, Bulgaria or Tadjikistan? The answer to these questions is I hope rather clear: scientific philosophy, or in other words a philosophy that respects the values of clarity, precision, seriousness, rigour and technical competence, is the product of an advanced intellectual culture and of the Western university. ("Why Polish Philosophy" 31)

Thus, a study of the influence of Brentano on Ukrainian philosophy (perhaps even an attempt to justify the existence of a certain period of "Ukrainian Brentanism") could not only examine the tradition of and prospects for the development of analytic (scientific) philosophy in Ukraine (see Vasyl'chenko and Panych), but also open new aspects of the modernization of Ukrainian society in general (from the end of the nineteenth century to the present day).

\section{RESEARCh METhODOLOGY}

What methodological approach could we take to find the right answer to this question? I believe that the methodology and terminological apparatus developed by Anna Brożek is suitable for this purpose. In her article "Franz Brentano and the Lvov-Warsaw School," Brożek examines the influence of Brentano on Polish philosophers belonging to the Lviv-Warsaw School. To characterize this influence, she analyzes the various forms of influence of 
one philosopher on another and proposes conceptual distinctions concerning such influence.

(1) Distinction between direct and indirect influence of one philosopher on another:

Assume that philosopher $A$ was a teacher of philosopher $B$ and that philosopher $B$ was a teacher of philosopher $C$. In such a situation, it is sometimes said that $C$ is $A$ 's "philosophical grandson." I would prefer to say in such a situation that $B$ is a direct and $C$ is an indirect successor of $A$. In this sense, Aristotle, as a student of Plato, was an indirect successor of Socrates, and Twardowski's students were indirect successors of Brentano. (Brożek 4)

(2) Distinction between active and passive contact between one philosopher and another:

Let us assume that $A$ and $B$ are philosophers. In order for the influence of $A$ on $B$ to occur, $A$ and $B$ have to have contact with each other. Not every contact results in influence, but a contact is at least a necessary condition of influence.

Philosopher $B$ may have contact with philosopher $A$ in many ways.

Let us consider a situation in which philosopher $B$ is a student of philosopher $A$. In such a situation, $B$ not only reads $A$ 's papers but also puts questions to $A$, presents his own results to $A$, is examined by $A$, prepares theses under $A$ 's supervision etc. Let us call this kind of contact of philosophers- "an active contact of philosopher $B$ with philosopher $A$ "....

An active contact of philosophers should be distinguished from a passive one. Philosopher $B$ passively has contact with philosopher $A$ when $B$ gets to know the works of $A$ but $B$ enters into no active relations with $A$. Active and passive relations (contacts) between philosophers may be also called, respectively: "having contact with philosopher $A$ " vs "having contact with A's philosophy." (Brożek 2)

By crossing these two distinctions, we get four possible kinds of influence of one philosopher on another:

(1) Direct influence on the basis of active contact ( $B$ was student of $A$ );

(2) Direct influence on the basis of passive contact ( $B$ was not student of A but got to know $A$ 's works);

(3) Indirect influence on the basis of active contact ( $B$ was a student of A's student);

(4) Indirect influence on the basis of passive contact ( $B$ was not student of $A^{\prime}$ s student but got to know works of $A$ 's student).

On the basis of the classification of influence presented above, the main question of whether Brentano influenced Ukrainian philosophy branches into the following four questions: 
(1) Were any Ukrainians influenced by Brentano directly on the basis of active contact (were any Ukrainians students of Brentano?)?

(2) Were any Ukrainians influenced by Brentano directly on the basis of passive contact (did any Ukrainians get to know works of Brentano without being his students?)?

(3) Were any Ukrainians influenced by Brentano indirectly on the basis of active contact (were any Ukrainians students of Brentano's students?)?

(4) Were any Ukrainians influenced by Brentano indirectly on the basis of passive contact (did any Ukrainians get to know works of Brentano's students without being their students?)?

Before searching for answers to these questions it should be noted that:

(a) active contact between two philosophers (following Brożek, let us call them $A$ and $B$ ) assumes the existence of an institutional bond between $A$ and $B$;

(b) both active and passive contacts can (as well as may not) lead to the appearance of an ideological bond between $A$ and $B$.

By "institutional bond," I mean the existence of a scientific institution wherein there is active contact between $A$ and $B$. Typically, such an institution is a university, and the relationship between $A$ and $B$ is a "professor-student" one. By "intellectual bond," I mean the existence of common ideas (concepts, terms, problems, methods) in the works of $A$ and $B .^{3}$ Note that the ideological bond is more important than the institutional bond. If the ideological bond is a necessary condition for the affiliation of $B$ to $A$ 's philosophical tradition, then the institutional bond is only a so-called "favourable" condition. This is clearly seen when considering the four logical possibilities for the fulfillment (or non-fulfillment) by $B$ of the conditions of institutional and ideological bonds with $A$ :

(a) If $B$ studied under $A$ (or his students) and accepted his ideas and/or used them in his works, then $B$ may be considered a follower of $A$.

(b) If $B$ studied under $A$ (or his students) but did not accept his ideas and/or did not use them in his works, then $B$ can not be considered a follower of $A .^{4}$

(c) If $B$ did not study under $A$ (or his students), but accepted his ideas and/or used them in his works, then $B$ could be considered a follower of $A$.

\footnotetext{
3 For example, in my article "Stefan Baley," I employ the concepts of institutional and ideological bonds to research the relationship between K. Twardowski and S. Baley.

${ }^{4}$ For example, Polish philosopher Benedykt Bornstein (1880-1948) studied under Twardowski at the University of Lviv, but did not accept and use Twardowski's ideas in his own works. Therefore, he can not be considered a follower of Twardowski.
} 
(d) If $B$ did not study under $A$ (or his students) and did not accept his ideas and/or did not use them in his works, then $B$ can not be considered a follower of $A$.

Consequently, we can distinguish between two groups of hypothetical Ukrainian followers of Brentano:

(a) Those who fulfill both institutional and ideological bond conditions;

(b) Those who do not fulfill the institutional bond condition, but who fulfill the ideological bond condition.

Quantitatively, the first group should significantly outperform the second group. After all, there is a greater chance that someone who has an active academic contact with a scholar (or with his students) will become a follower than someone who is simply familiar with the scholar's ideas (especially, this thesis is appropriate in the context of the nineteenth and the first half of the twentieth century, when scholarly publications were not as accessible as in the present era of the Internet). That is why great emphasis in our research will be placed on the institutional bond of Ukrainian philosophers with Brentano or his students (as a favourable condition of Brentano's influence).

\section{DIRECT INFLUENCE}

Question (1) is in principle equivalent to the question: "Were any Ukrainian academics Brentano's students at the Universities of Würzburg or Vienna?" The answer to that question is "hypothetically yes." We know for certain that many well-known Ukrainians (Ivan Levyts'kyi, Ievhen Kozak, Vasyl' Shchurat, Kyrylo Studyns'kyi et al.) studied in the Department of Philosophy at the University of Vienna at the time Brentano lectured there (between 1874 and 1895). However, currently there is no evidence that any of the aforementioned Ukrainians participated in Brentano's lectures. The search for such evidence would require a thorough and timeconsuming examination of the archives of the University of Vienna and the University of Würzburg.

The answer to question (2) involves only the possibility of Brentano's influence on Ukrainian philosophers in the "non-Austrian" part of Ukraine, namely the part of Ukraine that until 1917 was a part of the Russian Empire. For example, the study of Brentano's works in the Department of Philosophy at the University of Kyiv at the turn of the twentieth century is documented. In his university report, the Russian-Ukrainian philosopher Vasyl' Zen'kivs'kyi, who studied at the University of Kyiv between 1900 and 1909, mentions Brentano's opus magnum-Psychology from an Empirical Standpoint-as one of the books that provided a basis for his article "On the Question of the Function of Predicative" (Otchet 7; see also Zen'kovskii). 


\section{INDIRECT INFLUENCE}

Instead of searching for the Ukrainian "philosophical sons" of Brentano, it seems more promising to first search for his Ukrainian "philosophical grandsons" to answer question $3 .{ }^{5}$ In the two eastern crownlands of the Austro-Hungarian Empire, the Duchy of Bukovina and the Kingdom of Galicia and Lodomeria, Ukrainians were the notable ethnic group in the entire population. In the capitals (Chernivtsi and Lviv, respectively) of these two crownlands there were universities where vibrant educational work was conducted by former students of Brentano: Marty was a professor of philosophy from 1875-80 at the University of Chernivtsi, ${ }^{6}$ and Twardowski was a professor of philosophy from 1895-1931 at the University of Lviv. ${ }^{7}$

The first Brentanist who worked closely to the Ukrainian cultural environment was without any doubt Marty. He was appointed to the chair of philosophy at the University of Chernivtsi immediately after its foundation in 1875, due to the direct assistance of Brentano (Surman 355). Could Ukrainians be among Marty's students there?

According to the Austro-Hungarian census conducted in 1880, the national population in the Duchy of Bukovina was: $42.2 \%$ Ukrainian, $33.4 \%$ Romanian, and $24.4 \%$ other nationalities (Die Bevölkerung). Chernivtsi's national population was: $31.7 \%$ Jewish, $18.5 \%$ Ukrainian, and $14.4 \%$ Romanian; Ukrainians were fewer but still quite numerous (Special-OrtsRepertorien). At the same time the University of Chernivtsi was the smallest in the Empire (the average number of students in the 1875-1880 academic years was 200) and completely German-speaking during the entire "Austrian" period of its existence (1875-1919). These facts, and the fact that Marty worked at the University of Chernivtsi for a brief period of time, minimize (although do not make impossible) the probability that Ukrainians who would later be active in the field of philosophy were among his students at that time.

It might be more prospective to search for Brentano's influence among Marty's Ukrainian colleagues-lecturers, who specialized in philosophy and psychology. Among the latter, one could distinguish, for example, Klym Hankevych, who, like Marty, started to lecture at the University of Chernivtsi in 1875, and who was the author of one of the first textbooks on psychology written in Ukrainian (Korotkyi nacherk). However, Ivan

\footnotetext{
5 We will skip question 4 , as it has the same difficulties as question 2.

${ }^{6}$ Official German name: C. K. Franz Josephs Universität in Czernowitz.

7 Official German name: Sr. k.k. Majestät Franz I. höchten Namen fühenden Universität zu Lemberg.
} 
Franko, ${ }^{8}$ who had a very low opinion of the scientific level of Hankevych's papers, stated: "With the lectures [at the University of Chernivtsi], however, he was not lucky because it turned out quickly that he forged professor Schleicher's ${ }^{9}$ signature on his doctoral diploma" (367-68). ${ }^{10}$

Ukrainians were the largest national group in the eastern part of the Kingdom of Galicia and Lodomeria-so-called Eastern Galicia. According to general censuses conducted in 1910, the national population in Eastern Galicia was: 60\% Ukrainian, 24\% Polish, 12\% Jewish, and 3\% Austrian (German) (Nicieja). The national population in Eastern Galicia's capital city, Lviv, was: 51.7\% Roman Catholic, 18.2\% Greek Catholic, and 27.7\% Judaist, which basically reflects populations of Poles, Ukrainians, and Jews (Wiczkowski 36). ${ }^{11}$

As a consequence of Ukrainians' efforts to self-determine their own tradition and culture, by the end of the nineteenth century Lviv had become the major centre of Ukrainian science and culture. It was also very important that the University of Lviv, in the years 1871-1914, was the only university in the world in which lectures in the Ukrainian language were conducted. Although the abolition of the German language of instruction in 1871 was used by the Poles in their favour (in 1879, the Polish was approved as the official language of the university), Ukrainian language rights were taken into account. This was evidenced by the growth of the number of students of Ukrainian nationality and the number of classes held in the Ukrainian language. (Before World War I, ten chairs with the Ukrainian language of instruction functioned at the University of Lviv: three in the Department of Theology, four in the Department of Philosophy, and three in the Department of Law). Statistics of the students at the University of Lviv ${ }^{12}$ are shown in the following Table.

\footnotetext{
${ }^{8}$ Ivan Franko (1856-1914) was a prominent Ukrainian poet, writer, social and literary critic, and philosopher.

9 This obviously refers to August Schleicher (1821-68), professor of linguistics at Charles University in Prague.

10 All translations are my own.

11 For more on the multicultural character of Lviv, see Ivanyk, "The Lvov-Warsaw School."

12 Data according to C.K. Uniwersytet imienia Cesarza Franciszka I we Lwowie.
} 
Table. Students at the University of Lviv

\begin{tabular}{|c|c|c|c|}
\hline Semester & $\begin{array}{c}\text { Nationality of } \\
\text { students }\end{array}$ & $\begin{array}{c}\text { Faculty of } \\
\text { Philosophy }\end{array}$ & University \\
\hline \multirow[t]{4}{*}{$\begin{array}{c}\text { Winter } \\
1895 / 1896 \\
\end{array}$} & Poles & 96 & 736 \\
\hline & Ukrainians & 29 & 451 \\
\hline & Jews & 33 & 295 \\
\hline & Total & 162 & 1504 \\
\hline \multirow[t]{4}{*}{$\begin{array}{c}\text { Summer } \\
1898 / 1899\end{array}$} & Poles & 115 & 895 \\
\hline & Ukrainians & 34 & 545 \\
\hline & Jews & 34 & 354 \\
\hline & Total & 185 & 1819 \\
\hline \multirow[t]{4}{*}{$\begin{array}{c}\text { Winter } \\
1904 / 1905\end{array}$} & Poles & 621 & 1465 \\
\hline & Ukrainians & 216 & 812 \\
\hline & Jews & 130 & 1018 \\
\hline & Total & 988 & 2933 \\
\hline \multirow[t]{4}{*}{$\begin{array}{c}\text { Summer } \\
1904 / 1905\end{array}$} & Poles & 552 & 1347 \\
\hline & Ukrainians & 206 & 758 \\
\hline & Jews & 121 & 597 \\
\hline & Total & 893 & 2732 \\
\hline
\end{tabular}

Whereas there is not much information about Ukrainians who might have participated in Marty's lectures at the University of Chernivtsi, a statistics schedule of the nationality of students leaves no doubt that hundreds of Ukrainian students participated in Twardowski's classes in the Department of Philosophy at the University of Lviv. Further analysis of the biographies of Ukrainian intelligentsia living in the first half of the twentieth century shows that among these hundreds were at least several Ukrainian academics who significantly influenced the development of twentieth century Ukrainian culture and science. Besides philosophy in the strict sense of the word, the areas of research included mathematics, biology, physics, history, sociology, and linguistics, among others. Before the education reforms in Poland ${ }^{13}$ (in 1926 the Department of Philosophy at the University of Lviv was divided into the Department of Humanities

${ }^{13}$ Lviv was a part of Poland in the interwar period (1918-39). 
and the Department of Mathematics and Natural Sciences, and after 1936 the title "Doctor of Philosophy" was granted only to specialists in the field of philosophy), the various departments and disciplines were a part of the University of Lviv's Department of Philosophy, and they were often very remote from philosophy (in today's understanding of the term). "Doctors of Philosophy" coming from the University of Lviv also specialized in many other fields. But that does not mean that Twardowski's lectures did not influence the intellectual development of Ukrainian mathematicians, physicists, biologists, historians, archaeologists, and geographers who attended them. As the famous Ukrainian historian Ivan Kryp"iakevych wrote in his memoirs about his studies at the University of Lviv, "[p]hilosophy and mostly psychology were taught by Kazimierz Twardowski, a good pedagogue. Twardowski delivered his lectures very clearly; I had around 4-6 semesters of philosophy and I learned a lot" (90).

There is a copy of a paper read by the biologist Oleksandr Tysovs'kyi at the session of the Academic Reading Club headed by Twardowski. Without a doubt, Twardowski also influenced the development of Ukrainian pedagogy and didactics in Galicia. He was mentioned, among others, in Vasyl' Shchurat's Gimnazyial'na propedevtyka fil'ozofii (Introduction to Philosophy in Gymnasium) (4). Furthermore, Twardowski's textbook Podstawowe pojęcia dydaktyki i logiki (Basic Notions of Didactics and Logic), translated from Polish into Ukrainian by Myroslav Kapii, was supposed to be published in print in Kyiv between 1918 and 1919,14 about which Twardowski was informed in a letter from Kapii (Kazimierz Twardowski Archive K-02-1-15, 1,2). It is therefore worth mentioning that in Poland, not only philosophers in the strict sense of the word, but also representatives of other academic disciplines (for example, the linguist Jerzy Kuryłowicz, the literary critic Ostap Ortwin, the physician and theoretician of medicine Władysław Szumowski, and many other Polish scientists ${ }^{15}$ [Woleński 338-39]) are seen as Twardowski's followers. A similar influence on subjects apart from philosophy can be observed in the case of Brentano:

Brentano's influence was manifest not only in philosophy, as is obvious from names like Husserl and Meinong, but in other disciplines as well: psychology (with Stumpf, Ehrenfels and Meinong again), logic (in particular the Lviv-Warsaw School founded by Twardowski), literature

\footnotetext{
${ }^{14}$ In the end, the mentioned Ukrainan edition of Basic Notions of Logic and Didactics by Twardowski was not published in print (probably because of the fall of the Ukrainian National Republic in 1919).

15 For example, Zygmunt Zawirski was also an author of philosophical works in the strict sense of the word.
} 
(here one needs only to mention Franz Kafka and Robert Musil), and economics with the neoclassical theory of value. (Albertazzi et al. 8)

A list of the 46 most significant Ukrainian academics who studied philosophy at the University of Lviv under Twardowski is presented in the Appendix at the end of this article.

Apart from Marty and Twardowski, it is worth examining how other followers of Brentano influenced Ukrainian philosophy. At that time, Ukrainians studied not only in Lviv and Chernivtsi, but also at other centres of Brentanism in Austria, Germany, and Czechoslovakia. Ukrainian psychologist Iakym Iarema held a fellowship at the University of Graz between 1906 and 1908, where he probably attended Meinong's lectures; Stefan Baley, a psychologist, was a student of Stumpf at the University of Berlin between 1911 and 1912; Danylo Kernychnyi, a language specialist, was a student of Höfler at the University of Vienna between 1918 and 1922; Dmytro Chyzhevs'kyi, a philosopher, was a student of Husserl at the University of Freiburg between 1922 and 1923. Masaryk, in his turn, for many years provided patronage for the Free Ukrainian University in Prague, which functioned in the capital of Czechoslovakia between 1921 and $1945 .{ }^{16}$

\section{VERIFICATION OF INFLUENCE (CASE STUDY)}

The preceding discussion shows that many Ukrainians had active contact with Brentano's students, especially with Twardowski at the University of Lviv. But that does not mean that all these Ukrainians were philosophical grandsons of Brentano, as influenced indirectly by Brentano on the basis of active contact with his students. In section II we postulated that the most crucial verification of influence of philosopher $A$ on philosopher $B$ is the existence of an ideological bond between them. In Brożek's words:

An influence of philosopher $A$ on philosopher $B$ takes place only if the contact of $A$ with $B$ results in some actions or convictions of $B$. For instance, as a result of contact with philosopher $A$, philosopher $B$ starts to accept a certain thesis, takes a certain problem into account or applies a certain research method. (3)

Hence, a comparative analysis of Brentano's work and that of his hypothetic Ukrainian follower might reveal common theses, problems, and

\footnotetext{
${ }^{16}$ Alhough Masaryk never lectured at the Free Ukrainian University in Prague, his philosophical works were attentively studied and translated into Ukrainian by the professors of the university (see, for example, Halahan et al.; Iarema).
} 
research methods. Such analysis is attempted here using the work of Ilarion Svientsits'kyi, whose institutional bond with Twardowski is shown in the Appendix.

Svientsits'kyi (1876-1956) was a well-known Ukrainian philologist, ethnologist, museum expert, and socio-cultural activist. From 1905 to 1952 he was the director of the Church Museum in Lviv, from 1913 to 1939-the private docent, and from 1941 to 1950 - a professor of eastern and southern Slavic literatures at the University of Lviv. From 1914Svientsits'kyi was a member of The Shevchenko Scientific Society in Lviv, and from 1945-he was chairman of the Linguistics Department at the Institute of Social Sciences of the Academy of Sciences of the Ukrainian SSR in Lviv. Svientsits'kyi left a huge scientific legacy, mainly in the field of museology and the history of art. He was an author of several philosophical works, among which special attention should be paid to the historicophilosophical study entitled Nachala filosofii $v$ russkoi literature XI-XVI vv. (The Origins of Philosophy in Ruthenian ${ }^{17}$ Literature of the 11th-16th Centuries), which appeared in print in Lviv in 1901. This little-known work has a remarkable historical value because it can safely be considered one of the first attempts to sketch a history of Ukrainian philosophy. The author aimed to point out the philosophical ideas contained in Ruthenian literature of the 11th-16th centuries (based on an analysis of the source materials) and then to "discover their organic relationship and consistency" (Svientsits'kyi 2). The results of the analysis gave Svientsits'kyi a basis for the periodization of the history of Ruthenian philosophy:

(1) 11th-14th centuries (from Nestor the Chronicler to Metropolitan Cyprian);

(2) 15th-16th centuries (from Nil Sorskii to Zinovii Otenskii);

(3) 17th-18th centuries (associated with the scientific activity of Ostroh and Kyiv Academies);

(4) late 18th century-beginning of 20th century (connected with transplanting to the Russian ground the ideas of French encyclopedists and German systematics).

\footnotetext{
17 The noun and adjective "Ruthenian" (in Ukrainian "Русин" [noun] and "Руський" [adj.]; in Polish: "Rusin" [noun] and "Ruski” [adj.]) were used in Eastern Galicia until the first decades of the twentieth century and are actually counterparts of the modern "Ukrainian." It should be noted that at the time of the publication of his work, Svientsits'kyi was a follower of the so-called Russophilia movement, the spread of which among the Ukrainian population of Eastern Galicia was supported by the Russian Empire. The main idea of this movement was that Ukrainians (including Galician ones) are part of the Russian people. The language of Svientsits'kyi's monograph was also Russian.
} 
Svientsits'kyi observed certain regularities in the development of philosophy in Ruthenia (Rus'), which he based on the geographical factor of the distinguished periods. According to Svientsits'kyi, the development of philosophy in Ruthenia can be presented as the history of the regular flow of philosophical ideas between its two geographic "poles": the southwestern (later Ukraine) and the north-eastern (later Russia). The first distinguished period is the beginning of philosophical thought in southwestern Ruthenia with the centre in Kyiv, which was accompanied by an almost complete lack of philosophical ideas in north-eastern Ruthenia with the centre in Moscow. During the second period, the roles of these centres turned around, with almost complete intellectual stagnation in southwestern Ruthenia and a rapid development of philosophical thought in north-eastern Ruthenia. Svientsits'kyi notes that at the end of the second period one can observe the first signs of a next "change of roles": under the influence of Prince Andrei Kurbskii (who was a student of Maximus the Greek), Prince Konstiantyn Ostroz'kyi founded the Ostroh Academy in 1576. With the founding of the Academy, the rebirth of philosophical thought in south-western Ruthenia began, while in north-eastern Ruthenia in the late sixteenth century it almost disappeared.

At first glance, the work described above has no connection with Brentano's or even Twardowski's philosophy. But a closer examination of biographical documents leads to some unexpected conclusions. Svientsits'kyi was a student in the Faculty of Philosophy at the University of Lviv in 1895-99. During his studies, Svientsits'kyi surely attended Twardowski's lectures and made personal contact with this founder of the Lviv-Warsaw School. After his graduation in 1899, and probably thanks to the support of Twardowski, Svientsits'kyi received a one-year scholarship at the University of St. Petersburg, where he worked with the materials of the Imperial Public Library. According to Svientsits'kyi and Twardowski's correspondence from this period, the former collected in St. Petersburg materials for a doctoral dissertation on the history of philosophy in Ruthenia, and was supported in this endeavour by Twardowski. Thus, on 12 December 1899, Svientsits'kyi wrote to Twardowski:

Dear Professor Twardowski! I have been in St. Petersburg for three months, where I am studying at an archaeological institute with the intent to apply for a position of an archivist and a librarian in one of the Ruthenian libraries in Galicia.

Because classes at the institute only take up my evening hours, I devote my entire days to further historico-philosophical studies in the academic and public libraries, according to Your valuable advice that you gave me at the University of Lviv. My previous knowledge of the Ukrainian literary tradition gave me a research idea, and the present in-depth study of old Ukrainian literature shaped it into a plan: to present a history of 
philosophy in Rus' from the 11th to the 18th century inclusive. The material that I collected allows me even now to draw an outline of my intended research: centres of philosophical thought in Rus'; Greek and Western (Polish) influences; original philosophical thought. I am going to continue my research in this area in St. Petersburg until mid-March, and then complete it in Kyiv and Warsaw by Easter-so that at the beginning of the summer term I would be able to come to Lviv with a systematized material. Sharing the nature and direction of my study with You, I dare to inquire, whether such research could be accepted as a dissertation, and ask You for further valuable advice and comments. (Kazimierz Twardowski Archive K-02-1-37, 13-15)

In turn, in a letter written on 26 December 1899, we read:

I hurry to present to You the materials I currently possess and use .... I am examining the development of philosophical thought in each selected author in the following way: by studying the general picture of his views, I find the sources from which they originate. Having established these sources, I examine their consistency, their impact on the whole, and their relationship to further [philosophic] development. I will be very grateful to receive Your valuable guidelines on the submitted material and research plan. (Kazimierz Twardowski Archive K-02-1-37, 16-17)

However, Svientsits'kyi did not succeed in defending his doctoral thesis under Twardowski's supervision, ${ }^{18}$ probably because soon after his return to Lviv, in 1900, Svientsits'kyi was conscripted for one year of military service in the Austrian army. At the same time, Polish-Ukrainian relations in Lviv and Eastern Galicia became extremely strained. Nevertheless, there is no doubt that The Origins of Philosophy (1901) is in fact a publication of Svientsits'kyi's intended dissertation, prepared under Twardowski's supervision.

It is clear from Svientsits'kyi and Twardowski's correspondence that The Origins of Philosophy was written according to the methodological guidelines of the founder of the Lviv-Warsaw School. But what exactly could Twardowski's methodological guidelines consist of? Twardowski presented his views on the methodology of the history of philosophy in the article "Franciszek Brentano a historia filozofii" ("Franz Brentano and the History of Philosophy"), published in 1895. Referring to the classification given by the Polish historian of philosophy Maurycy Straszewski, Twardowski distinguished three methods of determining the history of philosophy:

\footnotetext{
${ }^{18}$ Finally, Svientsits'kyi defended his doctoral thesis Maximus the Greek in 1902 at the University of Vienna under the supervision of Vatroslav Jagić, a prominent Croatian scholar of Slavic studies (see Swiencickij).
} 
(1) Biographical method: the history of philosophy is presented as a history of the creators of philosophical ideas;

(2) Critical-reporting method: the history of philosophy is presented as a history of particular ideas and philosophical systems;

(3) Constructive method: the history of philosophy is revealed by considering the laws governing its development.

There are two types of constructive method:

(a) A priori constructive method: the history of philosophy is ordered according to predetermined laws governing its development;

(b) A posteriori constructive method: the laws of the development of philosophy are extracted from historical facts.

As Twardowski wrote, "It is obvious that the constructive method is the highest level of philosophical historiography and that only it can lead us to the understanding of the historical progress, which manifests itself in the philosophical sciences" ("Franciszek Brentano" 335).

From the two types of constructive method, Twardowski gave priority to the a posteriori one, as he considered it to be more scientific. A significant drawback of the a priori method is its tendency to deform facts in order to adapt them to preconceived laws of the development of philosophy. A reliable history of philosophy, which should be constructed using the a posteriori constructive method, is the "philosophy of the history of philosophy" or the "historiosophy of philosophy," and its tasks are (1) to indicate the general law according to which the historical development of philosophy is taking place and (2) to carry out the periodization of this development on the basis of such a law.

The a posteriori constructive method is the youngest and the most difficult method of determining the history of philosophy: successful examples of its use are few. Twardowski recognized that such pattern of determining the history of philosophy has been proposed in Die vier Phasen der Philosophie und ihr augenblicklicher Stand (The Four Phases of Philosophy and Its Present Condition), a work published in 1895 by his academic advisor, Brentano. In this work, Brentano put forward a hypothesis about the constant recurrence of four phases in the history of philosophy-two phases of flowering, and two phases of decline. Based on this historiosophical hypothesis, Brentano carried out an original periodization of the history of philosophy for four periods, each of which had the four phases mentioned above, and defined its present state as the beginning of the first phase of the new (fifth) period.

The form and content of Svientsits'kyi's The Origins of Philosophy clearly indicate that Twardowski suggested the use of the a posteriori constructive method to reconstruct the history of Ruthenian philosophy. The main goal of Svientsits'kyi's work was to demonstrate the law of "organic relationship and consequences" in the development of Ruthenian 
philosophy (2). This very law is supposed to be the basis for the periodization of the aforementioned development. According to Svientsits'kyi, such a law features a repetition of alternating phases:

(a) Flourishing of philosophy in south-western Ruthenia and collapse (or lack) of philosophy in north-eastern Ruthenia;

(b) Flourishing of philosophy in north-eastern Ruthenia and collapse of philosophy in south-western Ruthenia.

In this respect, one could interpret Svientsits'kyi's periodization of the development of philosophy in Ruthenia in the following way:

(1) 11th-14th centuries-phase (a);

(2) 15th-16th centuries-phase (b);

(3) 17th-18th centuries-phase (a);

(4) late 18th century-beginning of 20th century-phase (b).

The analysis carried out above entitles us to conclude that The Origins of Philosophy by Svientsits'kyi can be considered a successful and original example of the a posteriori constructive method implemented on Ukrainian historical ground. As Svientsits'kyi borrowed this method from Twardowski, and the latter borrowed this method from Brentano, Svientsits'kyi can be regarded as Brentano's philosophical grandson, or his indirect philosophical successor. Thus, it is possible to speak of Brentano's influence on Ukrainian philosophy on the basis of this concrete example. A similar method might verify the hypothetical presence of elements of Brentano's philosophy in the philosophical works of a wider group of Ukrainian scientists, such as those mentioned in previous sections and in the Appendix.

\section{CONCLUSION}

At the end of the nineteenth century and in the first decades of the twentieth century, Ukrainian students had contact with Brentano's philosophy not only during their studies in Vienna, Berlin, Graz, Freiburg, or Prague, but also in three big academic centres located on ethnical Ukrainian territory: the universities of Kyiv, Chernivtsi, and Lviv (especially the latter). Their teachers were often among Brentano's followers: Twardowski, Marty, Husserl, Meinong, Stumpf, Höfler, Masaryk. All facts discussed above support the hypothesis that Brentano had a significant influence on the development of Ukrainian philosophy, and that research to verify that hypothesis is not without merit. Further confirmation or rejection of the above-mentioned hypothesis would require an analysis of the philosophical works of the Ukrainian academics mentioned in this article and the scope of their theoretical and methodological affiliations with Brentano's philosophy. 
To quote a famous researcher of Ukrainian philosophy and culture, Chyzhevs'kyi, "[i]t is too early for the Ukrainian philosophy to write its history. But such an attempt is still possible. The author and the reader must consider their findings, as merely provisional, temporary, while bearing in mind that they can be corrected and adjusted by further research" (16). These words can be attributed to this article, which is an attempt to create a vision of one fragment of the history of Ukrainian philosophy. Its results do not pretend to be absolute truth, but an outline of possible ways to execute more thorough research in this direction in the future.

\section{Works Cited}

Abushenko, Vladimir. "Brentano." Noveishii filosofskii slovar', edited by Aleksandr Gritsanov, Izdatel' V. M. Skakun, 2003.

Albertazzi, Liliana, et al. "Introduction. Brentano and His School: Reassembling the Puzzle." The School of Franz Brentano, edited by Jan Srzednicki, Kluwer Academic Publishers, 1996.

Brentano, Franz. Die vier Phasen der Philosophie und ihr augenblicklicher Stand. Cotta, 1895.

---. On the Several Senses of Being in Aristotle. Edited and translated by Rolf George, U of California P, 1975.

---. Psychology from an Empirical Standpoint. Translated by Antos C. Rancurello et al., Routledge, 2009.

---. The Psychology of Aristotle: In Particular His Doctrine of the Active Intellect. Translated by Rolf George, U of California P, 1977.

Brożek, Anna. "Franz Brentano and the Lvov-Warsaw School." Academia.edu, https://www.academia.edu/36043332/AB Brentano FINIS. Accessed 3 Feb. 2019.

Chyzhevs'kyi, Dmytro. Narysy z istorii filosofii na Ukraini. Vydavnytstvo Orii pry UKSP Kobza, 1992.

C.K. Uniwersytet imienia Cesarza Franciszka I we Lwowie. Skład Uniwersytetu i program wykładów. Pierwsza Związkowa Drukarnia we Lwowie, 1896, 1899, 1902, 1905.

Dąmbska, Izydora. "Franciszek Brentano a polska myśl filozoficzna. Kazimierz Twardowski i jego szkoła." Ruch Filozoficzny, vol. 37, no. 1-2, 1979, pp. 1-10.

Die Bevölkerung der im Reichsrathe vertretenen Königreiche und Länder nach Aufenthalt und Zuständigkeit. Aus der Kaiserlich-Königlichen Hof und Staatsdruckerei, 1882.

Franko, Ivan. "Narys istorii ukrains'ko-rus'koi literatury do 1890 r." Zibrannia tvoriv u 50 tomakh, vol. 41, Naukova dumka, 1984.

Halahan, Mykola, et al., editors. Dobirni dumky prof. T. Harrik-Masaryka: z nahody 75 lit zhyttia, 1850-1925. Ukrains'kyi Hromads'kyi Komitet v Ch. S. R., 1925.

Hankevych, Klyment. Korotkyi nacherk psykholohii, dlia uzhytku $v$ shkolakh serednikh. V typohrafii i skladi Rudolfa Ekhardta, 1874.

Iarema, Iakym. Providni idei filosofii Tomy Masaryka. Z pryvodu 75-littia narodzhennia. Ukrains'kyi Hromads'kyi Vydavnychyi Fond, 1925. 
Ivanyk, Stepan. "The Lvov-Warsaw School as a Multicultural Phenomenon. Ukrainian Aspect." The Significance of the Lvov-Warsaw School in the European Culture, edited by Anna Brożek et al., Springer, 2017, pp. 29-44.

---. "Stefan Baley and the Lvov-Warsaw School." Tradition of the Lvov-Warsaw School: Ideas and Continuations, edited by Anna Brożek et al., Rodopi/Brill, 2016, pp. 279-87.

Kazimierz Twardowski Archive at the University of Warsaw.

Kryp"iakevych, Ivan. "Spohady (Avtobiohrafiia)." Ivan Kryp"iakevych u rodynnii tradytsii, nautsi, suspil'stvi, edited by Iaroslav Isaievych, Instytut ukrainoznavstva im. I. Kryp"iakevycha, 2001, pp. 306-29.

Nicieja, Stanisław. "Lwów-fenomen miasta wielu kultur i narodów." Przegląd Wschodni, vol. III, no. 4, 1994, pp. 717-32.

Novák, Josef, editor. On Masaryk. Rodopi, 1988.

Otchet o zaniatiiakh za 1910 god Professorskogo stipendiata pri kafedre filosofii Vasiliia Vasil'evicha Zen'kovskogo. State Archives of Kyiv, 16/465/3389.

Shchurat, Vasyl'. Gimnazyial'na propedevtyka fil'ozofii. Z pechati V. A. Shyikovs'koho, 1903.

Smith, Barry. Austrian Philosophy: The Legacy of Franz Brentano. Open Court, 1994.

---. "Why Polish Philosophy Does Not Exist." The Lvov-Warsaw School-The New Generation, edited by Jacek Juliusz Jadacki and Jan Paśniczek, Rodopi, 2006, pp. 19-39. Poznan Studies in the Philosophy of the Sciences and the Humanities 89.

Special-Orts-Repertorien der im Österreichischen Reichsrathe vertretenen Königreiche und Länder. Bd. 13: Special-Orts-Repertorium von Bukowina. Verlag der K.K. Statistischen Central Commission, 1885.

Surman, Jan. Habsburg Universities 1848-1918. Biography of a Space. 2012. University of Vienna, PhD dissertation.

Svientsits'kyi, Ilarion. Nachala filosofii $v$ russkoi literature XI-XVI vv. Izdanie "Halitsko-russkoi matitsy," 1901.

Swiencickij, Hilarion. Maksim der Grieche. University of Vienna, 1902. PhD dissertation. Archiv der Universität Wien, Pn. 1523, Fol. 8.

Twardowski, Kazimierz. "Franciszek Brentano a historia filozofii." Przełom, vol. I, no. 11,1885 , pp. 335-46.

---. Podstawowe pojęcia dydaktyki i logiki. Nakładem Towarzystwa Pedagogicznego, 1901.

Tysovs'kyi, Oleksandr. Referat na Kółko Filozoficzne. Central State Historical Archives of Ukraine in Lviv, 410/1/11.

Vasyl'chenko, Andrii, and Oleksii Panych. "Analitychna filosofiia v Ukraini: quo vadis?" Filosofs'ka dumka, no. 3, 2011, pp. 5-9.

Wiczkowski, Józef. Lwów, jego rozwój i stan kulturalny oraz przewodnik po mieście. Główny skład w księgarni H. Altenberga we Lwowie, 1907.

Woleński, Jan. Filozoficzna Szkoła Lwowsko-Warszawska. Państwowe Wydawnictwo Naukowe, 1985.

Zen'kovskii, Vasilii (Vasyl' Zen'kivs'kyi). "K voprosu o funktsiiakh skazuiemogo." Kievskie universitetskie izvestiia, no. 9, 1908, pp. 1-59. 


\section{Appendix}

Ukrainian academics who studied philosophy at the University of Lviv under Kazimierz Twardowski

\begin{tabular}{|c|c|c|c|}
\hline № & Name and Surname & Specialisation & $\begin{array}{c}\text { Date of } \\
\text { graduation }\end{array}$ \\
\hline 1 & $\begin{array}{c}\text { Mykola Andrusiak } \\
(1902-85)\end{array}$ & historian, Germanist & 1928 \\
\hline 2 & $\begin{array}{c}\text { Bohdan Ihor Antonych } \\
(1909-37)\end{array}$ & $\begin{array}{l}\text { poet, literary critic, } \\
\text { translator }\end{array}$ & 1933 \\
\hline 3 & $\begin{array}{l}\text { Stefan Baley } \\
(1885-1952)\end{array}$ & $\begin{array}{c}\text { philosopher, psychologist, } \\
\text { educationalist }\end{array}$ & 1907 \\
\hline 4 & $\begin{array}{c}\text { Ivan Bobers'kyi } \\
\text { (1873-1947) }\end{array}$ & $\begin{array}{l}\text { educationalist, theorist of } \\
\text { physical education }\end{array}$ & lack of data \\
\hline 5 & $\begin{array}{c}\text { Ivan Bryk } \\
(1879-1947)\end{array}$ & $\begin{array}{c}\text { philosopher, educationalist, } \\
\text { Slavist }\end{array}$ & 1901 \\
\hline 6 & $\begin{array}{c}\text { Tymotei Bilostots'kyi } \\
\text { (1905-95) }\end{array}$ & educationalist & lack of data \\
\hline 7 & $\begin{array}{l}\text { Klym Hlibovyts'kyi } \\
\text { (1875-1907) }\end{array}$ & mathematician, physicist & lack of data \\
\hline 8 & $\begin{array}{l}\text { Iulian Hirniak } \\
(1881-1970)\end{array}$ & $\begin{array}{l}\text { chemist, physicist, } \\
\text { mathematician }\end{array}$ & 1905 \\
\hline 9 & $\begin{array}{c}\text { Iaroslav Hordyns'kyi } \\
(1882-1939)\end{array}$ & $\begin{array}{l}\text { educationalist, translator, } \\
\text { historian of literature }\end{array}$ & 1904 \\
\hline 10 & $\begin{array}{c}\text { Mykhailo Halushchyns'kyi } \\
(1878-1931)\end{array}$ & educationalist, publicist & 1900 \\
\hline 11 & $\begin{array}{c}\text { Mykhailo Hrytsak } \\
\text { (lack of data) }\end{array}$ & $\begin{array}{l}\text { educationalist, } \\
\text { mathematician }\end{array}$ & lack of data \\
\hline 12 & $\begin{array}{l}\text { Petro Isaiv } \\
(1905-73)\end{array}$ & $\begin{array}{l}\text { historian, journalist, } \\
\text { educationalist }\end{array}$ & 1931 \\
\hline 13 & $\begin{array}{l}\text { Volodymyr Ianiv } \\
(1908-91)\end{array}$ & psychologist, sociologist & 1934 \\
\hline 14 & $\begin{array}{c}\text { Iakym Iarema } \\
(1884-1964)\end{array}$ & $\begin{array}{l}\text { psychologist, philosopher, } \\
\text { educationalist }\end{array}$ & 1906 \\
\hline 15 & $\begin{array}{c}\text { Volodymyr Iurynets' } \\
(1890-1937)\end{array}$ & philosopher & 1910 \\
\hline 16 & $\begin{array}{c}\text { Myroslav Kapii } \\
(1888-1949)\end{array}$ & $\begin{array}{c}\text { educationalist, writer, } \\
\text { translator }\end{array}$ & 1914 \\
\hline 17 & $\begin{array}{c}\text { Franz Kokovs'kyi } \\
(1885-1940)\end{array}$ & $\begin{array}{l}\text { jurist, journalist, } \\
\text { ethnographer }\end{array}$ & 1911 \\
\hline 18 & $\begin{array}{c}\text { Gabriel Kostelnyk } \\
(1886-1948)\end{array}$ & philosopher, theologian & 1910 \\
\hline
\end{tabular}




\begin{tabular}{|c|c|c|c|}
\hline 19 & $\begin{array}{l}\text { Dmytro Kozii } \\
(1894-1978)\end{array}$ & literary critic & lack of data \\
\hline 20 & $\begin{array}{c}\text { Antin Krushel'nyts'kyi } \\
(1878-1937)\end{array}$ & $\begin{array}{c}\text { educationalist, literary } \\
\text { critic }\end{array}$ & lack of data \\
\hline 21 & $\begin{array}{c}\text { Ivan Kryp"iakevych } \\
(1886-1967)\end{array}$ & historian, educationalist & 1908 \\
\hline 22 & $\begin{array}{c}\text { Ivan Kukhta } \\
\text { (1900-lack of data) }\end{array}$ & $\begin{array}{l}\text { psychologist, } \\
\text { educationalist, } \\
\text { ethnographer }\end{array}$ & 1925 \\
\hline 23 & $\begin{array}{l}\text { Volodymyr Kucher } \\
(1885-1970)\end{array}$ & mathematician, physicist & 1909 \\
\hline 24 & $\begin{array}{l}\text { Oleksandr Kul'chyts'kyi } \\
(1895-1980)\end{array}$ & $\begin{array}{l}\text { philosopher, psychologist, } \\
\text { educationalist }\end{array}$ & 1926 \\
\hline 25 & $\begin{array}{c}\text { Iaroslav Kuz'miv } \\
(1894-1945)\end{array}$ & educationalist, psychologist & lack of data \\
\hline 26 & $\begin{array}{l}\text { Severyn Levyts'kyi } \\
\text { (1890-lack of data) }\end{array}$ & educationalist & lack of data \\
\hline 27 & $\begin{array}{c}\text { Stanislav Liudkevych } \\
(1879-1979)\end{array}$ & $\begin{array}{c}\text { composer, musicologist, } \\
\text { educationalist }\end{array}$ & 1907 \\
\hline 28 & $\begin{array}{l}\text { Petro Mechnyk } \\
(1885-1953)\end{array}$ & $\begin{array}{l}\text { psychologist, logician, } \\
\text { educationalist }\end{array}$ & 1911 \\
\hline 29 & $\begin{array}{l}\text { Stepan Oleksiuk } \\
(1892-1941)\end{array}$ & $\begin{array}{l}\text { philosopher, psychologist, } \\
\text { literary critic }\end{array}$ & 1926 \\
\hline 30 & $\begin{array}{l}\text { Petro Pelekh } \\
(1887-1961)\end{array}$ & $\begin{array}{l}\text { psychologist, logician, } \\
\text { educationalist }\end{array}$ & 1910 \\
\hline 31 & $\begin{array}{c}\text { Ivan Rakovs'kyi } \\
\text { (1874-1949) }\end{array}$ & $\begin{array}{l}\text { educationalist, zoologist, } \\
\text { anthropologist }\end{array}$ & 1896 \\
\hline 32 & $\begin{array}{l}\text { Mykhailo Rybachek } \\
\text { (1874-1926) }\end{array}$ & $\begin{array}{l}\text { educationalist, } \\
\text { mathematician }\end{array}$ & lack of data \\
\hline 33 & $\begin{array}{l}\text { Milena Rudnyts'ka } \\
\quad(1892-1976)\end{array}$ & $\begin{array}{l}\text { educationalist, journalist, } \\
\text { feminist activist }\end{array}$ & 1914 \\
\hline 34 & $\begin{array}{c}\text { Iaroslav Rudnyts'kyi } \\
(1910-95)\end{array}$ & Slavist, linguist & 1934 \\
\hline 35 & $\begin{array}{c}\text { Mykhailo Rudnyts'kyi } \\
(1889-1975)\end{array}$ & literary critic, translator & 1914 \\
\hline 36 & $\begin{array}{l}\text { Stepan Rudnyts'kyi } \\
(1877-1937)\end{array}$ & geographer & 1901 \\
\hline 37 & $\begin{array}{c}\text { Ivan Starchuk } \\
(1894-1950)\end{array}$ & $\begin{array}{c}\text { art historian, } \\
\text { anthropologist, } \\
\text { archaeologist }\end{array}$ & lack of data \\
\hline 38 & $\begin{array}{c}\text { Olena Stepaniv-Dashkevych } \\
(1892-1963)\end{array}$ & educationalist & 1914 \\
\hline 39 & $\begin{array}{c}\text { Wolodymyr Shaian } \\
(1908-74)\end{array}$ & $\begin{array}{l}\text { Orientalist, philosopher, } \\
\text { psychologist }\end{array}$ & 1931 \\
\hline
\end{tabular}




\begin{tabular}{|c|c|c|c|}
\hline 40 & $\begin{array}{c}\text { Vira Svientsits'ka } \\
(1913-91)\end{array}$ & art historian & lack of data \\
\hline 41 & $\begin{array}{c}\text { Ilarion Svientsits'kyi } \\
(1876-1956)\end{array}$ & philologist, ethnographer & 1899 \\
\hline 42 & $\begin{array}{c}\text { Stepan Tomashivs'kyi } \\
(1875-1930)\end{array}$ & historian & 1911 \\
\hline 43 & $\begin{array}{c}\text { Oleksandr Tysovs'kyi } \\
(1886-1968)\end{array}$ & biologist & 1908 \\
\hline 44 & $\begin{array}{c}\text { Mykhailo Vozniak } \\
(1881-1954)\end{array}$ & $\begin{array}{c}\text { historian of literature, } \\
\text { folklorist }\end{array}$ & 1912 \\
\hline 45 & $\begin{array}{c}\text { Mykhailo Zales'kyi } \\
(1891-1965)\end{array}$ & Slavist \\
\hline
\end{tabular}

